\title{
Development of PPKn Module for the Love of the Environment Material Using Example Non Example Learning Model to Increase Student Learning Activities in Class II Public Elementary School 040446 Kabanjahe T.P. 2018/2019
}

\author{
Sari Jusnita Br Ginting, Dede Ruslan, Arif Rahman \\ State University of Medan, Indonesia \\ sarijusnita93@gmail.com
}

\begin{abstract}
This study produced a PPKn module on environmental love by using the example non example learning model to increase student learning activities. The research method used is the Research and Development method which refers to the development of Borg and Gall (in Tegeh et al, 2014: 7-13). The module development process is carried out with three stages, namely the preliminary study stage, initial product development and product trials. The results of the study show that the assessment of eligibility by material experts obtained an average of $91.6 \%$, the feasibility assessment by linguists obtained an average of 92, 1\%, Feasibility assessment by design experts obtained an average of $80 \%$. Individual trials with an average of $80.5 \%$ in the good category, small group trials with an average of $85.4 \%$ in the excellent category, and limited field trials with an average of $88.4 \%$ in the very good category. The results of observations of student activities observed an average of $92.4 \%$, The results of observations of student activities asked an average of $85.6 \%$, The results of observations of student activities tried with an average of $84.9 \%$, The results of observations of student activities associated with reasoning an average of $89.4 \%$, the results of observations of student activities communicate with an average of $83.9 \%$. The average score at 69.8 pretest and 82.3 at posttest. This proves that the PPKn module of environmental love material by using the example non example learning model is feasible, easy, and effective for use in class II grade students. This research has implications for the use of the PPKn module on environmental love material by using the example non example learning model to increase student activity and activity.
\end{abstract}

Keywords

module; love the environment; example non example

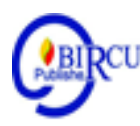

\section{Introduction}

Pancasila and Citizenship Education is a democratic education that aims to prepare citizens to think critically and act democratically through the activity of instilling awareness to the new generation that democracy is the form of life that best guarantees the rights of citizens.

Winarto (2006: 34) that PPKn learning has not been able to awaken the culture of learning in students. Culture of learning in this context means that learning PPKn not only involves "what to learn" but "how to learn". In other words learning PPKn should be seen from its instrumental aspects, namely "learning to learn". Analysis of external factors that affect the quality of the process and learning outcomes of PPKn found that students, parents, and even decision makers in the field of education tend to assume that PPKn has less benefits compared to other fields of study. 
Roestiyah (2008: 137) asserted that the lecture method is a way of teaching that is used to convey information or description of an issue and an oral problem. The advantages of using the lecture method in learning were stated by Arief (2002: 139). Among other things, the atmosphere of the class is running calmly because students do the same activities, do not require a lot of energy and a long time, lessons if implemented quickly, train students to pay attention well. Although the lecture method has several advantages, the lecture method also has some weaknesses as stated by Engkoswara (1984: 60-62) that the teacher acts as an authoritarian figure does not occur a "transactional" process between teacher and student, communication tends to be only one direction and very few teachers get feedback (feedback) from students, not maintaining student attention.

Students do not dare to ask because students do not understand what is explained by the teacher. So that students are not so enthusiastic in participating in learning. Teachers as transferring knowledge are often too active in the learning process, interactions between teachers and students in the learning process are not effective. If the learning process is more dominated by the teacher, then the effectiveness of learning will not be achieved. Teachers as educators do not dominate activities, but help create conducive conditions and provide motivation and guidance so students can develop their potential and creativity, through teaching and learning interactions.

The problem of student activeness in learning activities is caused by students not really understanding about the material delivered by the teacher or the students' low interest in reading due to the willingness of reading books such as textbooks is still limited. Based on observations obtained that the school actually has provided textbooks, but the material taught is not in accordance with the basic competencies of students as well as being still dominant in cognitive and less contextual aspects. Furthermore, based on the results of interviews of students themselves the package books provided are already unfit for use because they have been damaged and some pages have been lost, one of the efforts made by students is to copy a package book or take notes, but not all students make these efforts. Also when the learning process occurs, some students are busy going in and out of class, talking to their friends, busy tugging at their friends' books and sometimes laughing loudly. This indicates that students are interested in learning Low PPKn. Based on the facts above, there needs to be an improvement, from several types of teaching materials namely one of them is a module. Learning is done tends to be centered on the teacher. Students only take notes and work on the problems. Learning material has never been linked to real-life situations or the daily lives of students so students feel that learning of PPKn is abstract. This has an impact on the learning process that causes students to be unable to solve their own problems. Other findings were obtained that the factors that influence the low learning activities of students in the field of PPKn study at SD Negeri 040446 Kabanjahe.

So based on the above problems it can be concluded that activities related to student learning activities need to be improved to overcome this will be developed its own teaching material modules according to the needs of students. Teaching materials can be in the form of modules that are developed using the example non example model so that student learning activities can be increased. One of the teaching materials that can be developed is a module, because the preparation of modules is more practical than the preparation of audio media. One of the problems that occurred was that teachers at SD Negeri 040446 Kabanjahe never developed their own modules, this was due to the large amount of teaching materials that were ready to be used. The teaching material is not according to students' abilities. The learning system uses teaching materials, forcing students to follow the process while each 
student has different abilities. Students with low ability will have difficulty and feel bored in accepting PPKn learning materials in elementary schools.

The implementation of character education was not that easy as not all teachers were willing to take the time to integrate character education in classroom learning. Some teachers assumed that character education could interfere the effectiveness of the learning process. They revealed that character education should be the duty of parents, not teachers (Bohlin, 2005 , p. 3). In fact, the character education in classroom learning does not take a lot of time. This is because the character education curriculum is a nurturing effect or a hidden curriculum, in other words the character values are implied in every field of study. In addition, character education has an impact on improving students' cognitive abilities. Lickona in Rahmanisa (2018) states that character education can improve academic ability, because there will be a good relationship between the teachers and students and students with peers that will create an effective learning environment. In addition, character education will instill hard work habits that affect student education.

Thus, students are expected to understand the material is not only limited to theory but is equipped with examples of images to facilitate students in receiving material. Based on the above problems, the title of this research is "Development of PPKn Module on Environmental Love Material by Using Example Non Example Learning Model to Increase Student Learning Activities in Class II of SD Negeri 040446 Kabanjahe T.P. 2018/2019 "

Studying English is an important asset for vocational education students to answer various challenges in their professional world. The role of the lecturer is of course very important to facilitate students in obtaining adequate English language skills. Related to English lecturers who teach vocational education students (English for Specific Purposes) (Ottolini et al., 2010).they are asked to develop a Semester Program Plan (RPS) and Learning Implementation Plan (RPP) and develop teaching materials based on the needs of students. They must meet students' real-world professional demands effectively. However, the problems that occur in Indonesia, particularly in diploma three (D3) pharmacy department of Surabaya Pharmacy Academy, many English lecturers who teach in the field of vocational education, namely diploma three who have difficulty in designing Semester Program Plans (RPS) and Learning Implementation Plans (RPP) and teaching materials for diploma three (D3) pharmacy department of Surabaya Pharmacy Academy. Including teaching English at the Surabaya Pharmacy Academy, where lecturers find it difficult to design teaching materials due to the unavailability of special English books for vocational education students at the local bookstore. Therefore, analyzing the needs of students will be an alternative solution to the problem above.

Based on the above literature, needs analysis plays an important role in teaching because through needs analysis, lecturers / teachers, students, teaching materials, teaching procedures; all can be connected in harmony to improve the learning process of students (Wats and Wats, 2009, Robles, 2012, Shahroom and Hussin, 2018). Because of that researchers are motivated to conduct an analysis of the needs of English courses for students of D3 departments of Pharmacy Academy of Pharmacy Surabaya. This research is the first stage of a series of future studies in the process of developing and evaluating teaching material in English vocational education courses. Analysis of student needs will be the initial focus in designing and developing teaching materials. This research is important to do in order to facilitate lecturers in developing teaching materials and can also help vocational education students in accessing the specific language they need in order to be able to communicate appropriately according to the demands of their work world. In the future, it is expected that the resulting formulation will be used to compile and develop instructional 
content and instructional strategies (both in the form of teaching modules, techniques, applications and others) to assist teachers / lecturers in teaching and learning in class

\section{Review of Literature}

\subsection{Module Theory}

Modules are teaching materials that are arranged systematically in a language that is easily understood by students, according to their age and level of knowledge so that they can learn independently with minimal guidance from educators. The use of modules in learning aims to enable students to learn independently without or with a minimum of from the teacher. In learning, the teacher is only a facilitator.

Asyhar (2011: 155) module is one form of print-based teaching materials that are designed for independent learning by students. Therefore, the module is equipped with instructions for self-study.

Mulyasa (2004: 43-45) module is a package of independent learning that includes a series of learning experiences that are planned and systematically designed to help students achieve learning goals.

So it can be concluded that the module is a teaching material designed by the teacher equipped with instructions for independent learning packed with the aim of increasing student learning activities.

Based on the definition of the Sudjana and Rivai modules (2007: 134) and Suhardi (2012: 49), the elements contained therein are as follows: a. Formulation of special learning objectives. The learning objectives are formulated in the form of student behavior. b. Study instructions, containing an explanation of how learning can be held efficiently. c. Student Worksheet, contains subject matter that must be mastered by students. d. The practice and assignment sheets contain questions and problems that must be answered by students. e. The answer to the exercises and assignments, the aim is that students can evaluate the results of their work. f. Formative Test Sheets, an evaluation tool to measure student success in achieving the goals that have been formulated in the module. g. Summary, contains a summary of the material to strengthen understanding of the subject matter. h. Key Formative test sheets, the goal is that students can evaluate the results of their work. The module that is developed must have the characteristics needed as a module to be able to produce modules that are able to increase the motivation of its users. According to the Directorate of Vocational High School Development (2008: 4-7), the module to be developed must pay attention to the five characteristics of a module, namely self instruction, self contained, stand alone, adaptive, and user friendly.

Learning modules are arranged based on the principles of developing a module, including needs analysis, module design development, implementation, assessment, evaluation and validation, as well as quality assurance. The development of a module design is carried out in stages, namely establishing learning strategies and media, producing modules, and developing assessment tools. Thus, the modules are arranged based on a predetermined design. In this context, the module design is determined based on the Learning Implementation Plan (RPP) that has been prepared by the teacher. The module framework in this guideline has been established, so that it is possible for schools to directly implement or be able to modify it as needed without having to reduce the minimum provisions that must be contained in a module.

The material or content of the modules written must be in accordance with the Learning Implementation Plan (RPP) prepared. The contents of the module include the substance needed to master a competency. It is strongly recommended that one competency can be 
developed into one module, but taking into account the specific characteristics, breadth and complexity of the competency, it is possible for one competency to be developed into more than one module. Furthermore, one module is recommended to consist of 2-4 learning activities. If the existing competency standards in the Curriculum / Syllabus / RPP have more than 4 basic competencies, then it is better to reorganize competency standards (SK) and basic competencies (KD) first.

\subsection{Example Non Example Learning Model}

Example non example learning model is a series of delivery of teaching material to students by showing relevant pictures that have been prepared and given the opportunity for students to analyze it with peers in groups who are then asked the results of the discussion he did. Istarani (2011: 9)

The example non example model is one of the Group investigation approaches in cooperative learning that is designed to influence student interaction patterns and increase academic achievement. This type of learning is intended as an alternative to the traditional classroom learning model and requires students to help each other in small groups and is more characterized by cooperative appreciation than individuals. (Ibrahin 2000: 3)

So, the example non example learning model departs from the documentation data which is then developed into a study of interesting teaching material to be studied and examined in order to obtain a very useful knowledge that was previously unknown. Thus, what guides the teacher in the delivery of teaching material to students is the pictures. Every type and form of description done by the teacher departs from the existing pictures. From the picture the teacher explains as wide as possible, as deep and as long as possible the teaching material to students.

\subsection{Implementing Modules in Example Non Example}

The position of design in module development is as one of the components of the development principle that underlies and gives technical direction and stages of module preparation. In developing modules, there are a number of principles that need attention. Modules must be developed on the basis of the results of the needs and conditions analysis. Subsequently, a module design was developed using a non-example example model which was judged to be the most appropriate with various objective data and information obtained from the analysis.

Based on the designs that have been developed, modules are arranged according to the modules needed. The module preparation process consists of three main stages. First, determine learning strategies and appropriate learning media. At this stage, it is important to consider various characteristics of competencies to be learned, student characteristics and characteristics of the context and situation in which the module will be used.

The module development design using the example non example learning model at the elementary level aims to convey PPKn materials that must be mastered by students in accordance with the established KI-KD syllabus, also can be a media in shaping the character of students into a person who views the uniqueness of humans by regardless of race, culture, and smart, skilled, and character (Love the Environment). Realization of PPKn learning objectives requires modules that support the learning process. Based on preliminary studies in the field, it was found that in the learning process there were no PPKn modules available that integrated the values of environmental love in the material. 


\subsection{The nature of PPKn}

The nature of PPkn as an educational program based on Pancasila values is to develop and preserve noble and moral values that are rooted in the nation's culture which are expected to be identity manifested in the form of behavior in daily life. Learning in self-formation that varies in terms of religion, socio-culture, language, and ethnicity focuses on the formation of citizens who understand and are able to exercise their rights and obligations to become intelligent, skilled, and characterized Indonesian citizens.

Susanto (2013: 225), Pancasila Education and Citizenship are subjects used as a vehicle to develop and preserve noble and moral values that are rooted in Indonesian culture.

Samsuri (2011: 28), Pancasila and Citizenship Education is defined as preparing young people (students) to become citizens who have the knowledge, skills and values needed to actively participate in their communities.

From the explanation above, it can be concluded that the Pancasila and Citizenship Education subjects in elementary schools have a role to equip students in developing social attitudes by paying attention to the values and rules that apply and preparing students to become Indonesian citizens who love and are proud of all their contents and diversity. .

\subsection{Learning Activities}

Activities are principles or principles that are very important in teaching and learning interactions. Learning activities have some orientation to the view of psychology, namely the views of old psychology and modern psychology. According to the old psychology view activity is dominated by the teacher, whereas according to the modern psychology view the learning activity is dominated by students. Learning activities are very important for students, because they provide opportunities for students to explore broadly with the objects experienced and the learning environment. Sardiman (2006: 100) states that learning activities are physical and mental activities. In learning activities both are interrelated. Hamalik (2009: 179) states that learning activities is an activity carried out by students in learning activities. Learning activities can be realized if students are actively involved in learning. Yamin (2007: 82) defines active learning as a human effort to build knowledge in him. Learning will produce a change and increase the ability, knowledge and skills in students. Students are able to explore their abilities with their curiosity so that the interaction that occurs will be an experience and a desire to know something new.

Based on the opinion above, it can be concluded that learning activities are activities or actions both physical and mental carried out by individuals to build knowledge and skills in self in learning activities. Learning activities will make learning effective. The teacher does not only convey knowledge and skills. However, the teacher must be able to bring students to be active in learning.

\subsection{Framework}

Research and development carried out aims to develop a product. The step in developing a product is done by analyzing the needs of teachers and students. The results of initial school observations note that teachers are difficult to arouse student motivation to learn, students tend to be passive, teaching materials used are textbooks that have not been designed by the teacher, student learning activities are low, and students want attractive learning media that can increase activities student learning.

Based on these problems, it is necessary to develop a product in the form of a module to help facilitate student learning, because the module can be designed by the teacher, so the teacher can innovate to improve student learning activities, PPKn learning modules are developed through a model, Example non example because the principle of the model 
example is non example is a series of delivery of teaching material to students by showing relevant pictures that have been prepared and given the opportunity for students to analyze it with peers in groups who are then asked to discuss the results of what they do. The example non example model is one of the group investigation approaches in cooperative learning that is designed to influence student interaction patterns and increase academic achievement. This type of learning is intended as an alternative to the traditional classroom learning model and requires students to help one another in small groups and is more characterized by cooperative appreciation than individuals. The development of PPKn modules through the example non example learning model in this study uses Research and Development, or commonly known as (R\&D). This research method is not aimed at finding / making theories, but this research aims to make a certain product. Research and Development is a research method used to produce certain products, and test the effectiveness of these products.

\section{Method}

This research uses the type of Research and Development research, or commonly known as (R\&D). This research method is not aimed at finding / making theories, but this research aims to make a certain product. Sugiyono (2010: 297), Research and Development is a research method used to produce certain products, and test the effectiveness of these products.

In this case, the researcher developed a learning product in the form of the Citizenship Education Module for the love of the environment material for Grade II Elementary School students.

Research on Development of PPKn modules on environmental love material by using a non-example example learning model To Increase Student Learning Activities is planned in Class II of SD Negeri 040446 2018/2019. The implementation time is January to February 2020.

The population in this research and development are all grade II students of SD Negeri 040446 Kabanjahe. The sample set in this study amounted to 28 students.

\section{Discussion}

\subsection{Eligibility for Learning Module PPKn Material Love the Environment by Using the \\ Example non Example Learning Model}

The feasibility of the module is obtained based on the results of the validation of the expert team of material experts and design experts after being validated, the products are tested on individual students, small groups and limited field groups. The following will explain the module feasibility test.

The module development products are validated by Dr. Deny Setiawan, M.Si is a PPKn Learning module on environmental love material by using the example non example learning model. Expose the results of the assessment of the results of the material experts submitted through a questionnaire instrument in the form of a questionnaire on the learning module PPKn environmental love material by using the example non example learning model. Data can be seen in the table as follows: 
Table 1. Evaluation of Material Expert Validation Results

\begin{tabular}{|c|c|c|}
\hline Rated aspect & \begin{tabular}{|c} 
Revision \\
1 \\
\end{tabular} & $\begin{array}{c}\text { Revision } \\
2 \\
\end{array}$ \\
\hline $\begin{array}{l}\text { 1. Learning objectives and indicators are clearly } \\
\text { stated }\end{array}$ & 3 & 4 \\
\hline $\begin{array}{l}\text { 2. Match learning objectives with } \\
\text { competency indicators }\end{array}$ & 3 & 4 \\
\hline 3. Suitability of KD integration & 3 & 3 \\
\hline $\begin{array}{l}\text { 4. The suitability of learning activities with the } \\
\text { formulation of indicators }\end{array}$ & 2 & 3 \\
\hline $\begin{array}{l}\text { 5. The suitability of learning activities with learning } \\
\text { objectives }\end{array}$ & 3 & 4 \\
\hline $\begin{array}{l}\text { 6. The breadth and depth of the content of the } \\
\text { material presented in accordance with the } \\
\text { competency indicators }\end{array}$ & 3 & 4 \\
\hline 7. Clarity of material presented & 3 & 3 \\
\hline 8. Accuracy of chapter titles with content & 3 & 4 \\
\hline 9. The truth of the material substance & 3 & 4 \\
\hline $\begin{array}{l}\text { 10. The truth of theories and concepts in the scientific } \\
\text { field }\end{array}$ & 3 & 3 \\
\hline $\begin{array}{l}\text { 11. Compatibility of images with the contents of the } \\
\text { material }\end{array}$ & 4 & 4 \\
\hline 12. The accuracy of the image in clarifying the material & 3 & 3 \\
\hline $\begin{array}{l}\text { 13. Organizing the material describes the unit of material } \\
\text { that is intact and mutually integrated }\end{array}$ & 4 & 3 \\
\hline 14. Material is arranged systematically & 4 & 3 \\
\hline $\begin{array}{l}\text { 15. Learning is compatible with } \\
\text { the needs of grade II elementary school students }\end{array}$ & 4 & 4 \\
\hline $\begin{array}{l}\text { 16. The exercises provided are relevant to the scope } \\
\text { Theory }\end{array}$ & 3 & 4 \\
\hline $\begin{array}{l}\text { 17. Evaluation questions are relevant to the scope of the } \\
\text { material }\end{array}$ & 3 & 4 \\
\hline $\begin{array}{l}\text { 18. The level of difficulty of the questions is relevant to } \\
\text { students' abilities }\end{array}$ & 3 & 4 \\
\hline Total & 57 & 65 \\
\hline Average & 3,16 & 3,61 \\
\hline Percentage & $79,1 \%$ & $90,2 \%$ \\
\hline Criteria & Good & $\begin{array}{l}\text { Very } \\
\text { Good }\end{array}$ \\
\hline
\end{tabular}

The module development products are validated by Dr. M. Okky Fardian Gafari, M.Hum. is to give an assessment as a linguist. Validation is given in the form of a questionnaire instrument in the form of a questionnaire against the module. Data can be seen in the table as follows: 
Table 2. Evaluation of Language Expert Validation Results

\begin{tabular}{|c|c|c|}
\hline Rated aspect & $\begin{array}{c}\text { Revision } \\
1\end{array}$ & $\begin{array}{l}\text { Revision } \\
2\end{array}$ \\
\hline \multicolumn{3}{|l|}{ Component Eligibility for Content } \\
\hline 1. Cover & 2 & 4 \\
\hline 2. $\quad$ Preface & 3 & 3 \\
\hline 3. Table of contents / table & 3 & 3 \\
\hline 4. Guidelines for using textbooks & 2 & 3 \\
\hline 5. Competence & 3 & 4 \\
\hline 6. Learning objectives & 3 & 4 \\
\hline 7. Material description & 3 & 4 \\
\hline 8. Student learning activities (worksheet) & 3 & 4 \\
\hline 9. Picture & 2 & 4 \\
\hline 10. Evaluation & 3 & 4 \\
\hline 11. Competence test & 3 & 4 \\
\hline 12. references & 3 & 4 \\
\hline \multicolumn{3}{|l|}{ Language Components } \\
\hline $\begin{array}{l}\text { 13. In accordance with the level of development } \\
\text { learners }\end{array}$ & 3 & 4 \\
\hline 14. Communicative and interactive & 3 & 4 \\
\hline 15. Straightforward & 2 & 3 \\
\hline 16. Language suitability & 2 & 3 \\
\hline Total & 43 & 59 \\
\hline Average & 2,68 & 3,68 \\
\hline Percentage & $67,1 \%$ & $92,1 \%$ \\
\hline Criteria & Good & Very good \\
\hline
\end{tabular}

The module development products are validated by Drs. Sriadhi, M.Pd., M.kom, Phd. PPKn module is an environmental love material by using the example non example learning model in the form of a module. Validation submitted through questionnaire questionnaire instrument to the module. Data can be seen in the table as follows

Table 3 Evaluation of Design Expert Validation Results

\begin{tabular}{|c|c|c|c|}
\hline Sub Component & Rating Indicator & $\begin{array}{c}\text { Revision } \\
1\end{array}$ & $\begin{array}{c}\text { Revision } \\
2\end{array}$ \\
\hline \multirow[t]{3}{*}{ A. Display Text } & $\begin{array}{l}\text { Size match } \\
\text { with ISO } 216 \text { standards (A4, A5 and } \\
\text { B5) }\end{array}$ & 4 & 4 \\
\hline & Size match with material & 3 & 4 \\
\hline & $\begin{array}{l}\text { The appearance of the layout elements } \\
\text { on the cover face, back and back in } \\
\text { harmony has a rhythm and unity as } \\
\text { well } \\
\text { consistent. }\end{array}$ & 3 & 4 \\
\hline
\end{tabular}




\begin{tabular}{|c|c|c|c|}
\hline & $\begin{array}{l}\text { Showing center of view (center point) } \\
\text { the good one. }\end{array}$ & 3 & 3 \\
\hline & $\begin{array}{l}\text { Layout element color } \\
\text { harmonious and clarifying functions. }\end{array}$ & 4 & 4 \\
\hline & $\begin{array}{l}\text { Composition and size } \\
\text { layout element (title, author, } \\
\text { illustration, logo and others) } \\
\text { proportional, balanced, } \\
\text { and in tune with the content layout } \\
\text { (according to the pattern). }\end{array}$ & 3 & 3 \\
\hline & $\begin{array}{l}\text { The module title letter size is more } \\
\text { dominant and proportional compared } \\
\text { to size, } \\
\text { author's name. }\end{array}$ & 3 & 3 \\
\hline \multirow[t]{9}{*}{ B. Image Display } & $\begin{array}{l}\text { The module title color contrasts with } \\
\text { the color } \\
\text { background. }\end{array}$ & 3 & 3 \\
\hline & $\begin{array}{l}\text { Do not use } \\
\text { too many font combinations. }\end{array}$ & 3 & 3 \\
\hline & $\begin{array}{l}\text { Describe the content / teaching } \\
\text { material and express character } \\
\text { object. }\end{array}$ & 3 & 3 \\
\hline & $\begin{array}{l}\text { Shape, color, size, proportion of } \\
\text { objects according to reality. }\end{array}$ & 4 & 4 \\
\hline & $\begin{array}{l}\text { Layout layout elements are consistent } \\
\text { based on patterns }\end{array}$ & 3 & 4 \\
\hline & $\begin{array}{l}\text { Separation between paragraphs } \\
\text { clear }\end{array}$ & 4 & 3 \\
\hline & $\begin{array}{l}\text { Printing and margins } \\
\text { proportional }\end{array}$ & 3 & 3 \\
\hline & $\begin{array}{l}\text { Side by side margins } \\
\text { proportional }\end{array}$ & 3 & 3 \\
\hline & $\begin{array}{l}\text { Space between text and } \\
\text { illustrations accordingly }\end{array}$ & 2 & 3 \\
\hline
\end{tabular}




\begin{tabular}{|c|c|c|c|}
\hline \multirow[t]{9}{*}{$\begin{array}{l}\text { C. } \\
\text { Vict or y }\end{array}$} & $\begin{array}{l}\text { Placement of learning activity titles, } \\
\text { learning activity subtitles, and } \\
\text { exact page / folio number }\end{array}$ & 3 & 3 \\
\hline & $\begin{array}{l}\text { Placement of illustrations and image } \\
\text { captions } \\
\text { (caption) right }\end{array}$ & 3 & 3 \\
\hline & $\begin{array}{l}\text { Placement of decoration / illustration } \\
\text { as a background does not interfere } \\
\text { with the title, text, } \\
\text { page numbers. }\end{array}$ & 3 & 3 \\
\hline & $\begin{array}{l}\text { Placement of titles, subtitles, } \\
\text { illustrations, and image captions is } \\
\text { not } \\
\text { disturbing understanding. }\end{array}$ & 3 & 3 \\
\hline & $\begin{array}{l}\text { Do not use } \\
\text { too many font types. }\end{array}$ & 4 & 4 \\
\hline & $\begin{array}{l}\text { The use of letter variations (bold, } \\
\text { italic, all capital, small capital) no } \\
\text { exaggerated. }\end{array}$ & 3 & 3 \\
\hline & $\begin{array}{l}\text { Spacing between arrangement lines } \\
\text { normal text. }\end{array}$ & 2 & 3 \\
\hline & $\begin{array}{l}\text { Spacing between letters } \\
\text { (kerning) normal. }\end{array}$ & 3 & 3 \\
\hline & $\begin{array}{l}\text { Levels / hierarchy of titles clear, } \\
\text { consistent and } \\
\text { proportional. }\end{array}$ & 3 & 3 \\
\hline
\end{tabular}




\begin{tabular}{|c|l|c|c|}
\hline $\begin{array}{l}\text { D. } \begin{array}{l}\text { Cohesivenes } \\
\mathrm{s}\end{array} \\
\text { (hyphenation). }\end{array}$ & 3 & 3 \\
\cline { 2 - 4 } & $\begin{array}{l}\text { Able to uncover } \\
\text { the meaning / meaning of the object. }\end{array}$ & 3 & 3 \\
\cline { 2 - 4 } & $\begin{array}{l}\text { Accurate and proportional shapes } \\
\text { accordingly } \\
\text { with reality. }\end{array}$ & 3 & 3 \\
\cline { 2 - 4 } & Creative and dynamic & 3 & 3 \\
\hline & \multicolumn{1}{|c|}{ Total } & $\mathbf{3 , 1}$ & $\mathbf{3 , 2}$ \\
\hline & Average & $\mathbf{7 7 , 5 \%}$ & $\mathbf{8 0 \%}$ \\
\hline & Percentage & $\mathbf{G o o d}$ & $\mathbf{G o o d}$ \\
\hline
\end{tabular}

Teacher assessment is also needed to develop PPKn learning modules on environmental love material using the example non example learning model. This module assessment was carried out by two teachers of Class II Public Elementary School 040446 Kabanjahe. It aims to obtain information about the quality of the modules developed so that it can be adjusted to the cognitive level of Class II students of SD Negeri 040446 Kabanjahe. The results of the study conducted by the teacher showed that the PPKn learning module on environmental love material by using the example non example learning model was in the category of "Very Good" with an average percentage of $85.5 \%$. The results of the teacher's assessment of the module can be seen in table 4 . Below.

Table 4. Data Results of Teacher Responses to Modules

\begin{tabular}{|c|c|c|c|c|}
\hline No & Component & Indicator & $\%$ & Criteria \\
\hline \multirow[t]{3}{*}{1} & \multirow[t]{3}{*}{ Content } & $\begin{array}{l}\text { 1. The material in the } \\
\text { module matches } \\
\text { the objectives } \\
\text { learning }\end{array}$ & 87,5 & $\begin{array}{l}\text { Very } \\
\text { Good }\end{array}$ \\
\hline & & $\begin{array}{l}\text { 2. The material in the module } \\
\text { is related to the theme of } \\
\text { environmental love } \\
\text { material by using learning } \\
\text { models example non } \\
\text { example }\end{array}$ & 87,5 & $\begin{array}{l}\text { Very } \\
\text { Good }\end{array}$ \\
\hline & & $\begin{array}{l}\text { 3. Material in the } \\
\text { module related to } \\
\text { thematic }\end{array}$ & 87,5 & $\begin{array}{l}\text { Very } \\
\text { Good }\end{array}$ \\
\hline
\end{tabular}




\begin{tabular}{|c|c|c|c|c|}
\hline & & $\begin{array}{|lr|}\text { Module } & \text { material } \\
\text { enrich } & \text { student } \\
\text { knowledge } & \end{array}$ & 87,5 & Good \\
\hline & & $\begin{array}{l}\text { 5. Learning activities } \\
\text { stimulate abilities } \\
\text { critical thinking }\end{array}$ & 87,5 & $\begin{array}{l}\text { Very } \\
\text { Good }\end{array}$ \\
\hline & & $\begin{array}{l}\text { 6. Modules make it easy for } \\
\text { students to get to deeper } \\
\text { understanding in regarding } \\
\text { material that exists through } \\
\text { pictures }\end{array}$ & 87,5 & $\begin{array}{l}\text { Very } \\
\text { Good }\end{array}$ \\
\hline & & $\begin{array}{l}\text { 7. Modules help } \\
\text { teachers evaluating } \\
\text { students }\end{array}$ & 87,5 & $\begin{array}{l}\text { Very } \\
\text { Good }\end{array}$ \\
\hline 2 & Bahasa & $\begin{array}{l}\text { 8. The language used in } \\
\text { accordance with PUEBI }\end{array}$ & 75 & Good \\
\hline & & $\begin{array}{l}\text { 9. The language used } \\
\text { easy to understand }\end{array}$ & 87,5 & $\begin{array}{l}\text { Very } \\
\text { Good }\end{array}$ \\
\hline & & $\begin{array}{l}\text { 10. Usage Guidelines } \\
\text { clearly illustrated }\end{array}$ & 87,5 & $\begin{array}{l}\text { Very } \\
\text { Good }\end{array}$ \\
\hline 3 & Presentation & $\begin{array}{l}\text { 11. The overall module } \\
\text { appearance is interesting }\end{array}$ & 87,5 & $\begin{array}{l}\text { Very } \\
\text { Good }\end{array}$ \\
\hline & & $\begin{array}{l}\text { 12. Presentation of material } \\
\text { and the images in the } \\
\text { module are arranged } \\
\text { systematically }\end{array}$ & 87,5 & $\begin{array}{l}\text { Very } \\
\text { Good }\end{array}$ \\
\hline \multicolumn{3}{|c|}{ Total } & 85,5 & $\begin{array}{l}\text { Very } \\
\text { Good }\end{array}$ \\
\hline
\end{tabular}

Field trials conducted 28 students II Public Elementary School 040446 Kabanjahe. Limited field trials produce data that will be used to find out how the benefits of the product for students. The results of limited field trials show that the PPKn Learning module on environmental love material using the example non example learning model is in the category of "Very Good" with a percentage of $88.99 \%$. Textbooks have been declared feasible but have not reached $100 \%$. This is because not all students who fill in the questionnaire with very good criteria means that there are still some students who fill in the questionnaire with 
good criteria therefore the module is ready to be tested for effectiveness. Data on the results of limited field trials can be seen in table 5 below.

Table 5 Data from the Field Trial Results are Limited to Modules

\begin{tabular}{|c|c|c|c|c|}
\hline No & Component & Content & $\begin{array}{l}\text { Percent } \\
\text { age }\end{array}$ & Criteria \\
\hline \multirow[t]{9}{*}{1} & Theory & $\begin{array}{l}\text { 1. Is material in } \\
\text { this module } \\
\text { it's easy to } \\
\text { understand }\end{array}$ & 91 & $\begin{array}{l}\text { Very } \\
\text { Good }\end{array}$ \\
\hline & & $\begin{array}{l}\text { 2. Is the language used } \\
\text { in the module easy } \\
\text { understandable }\end{array}$ & 88,3 & $\begin{array}{l}\text { Very } \\
\text { Good }\end{array}$ \\
\hline & & $\begin{array}{l}\text { 3. Is a picture in the } \\
\text { module in accordance } \\
\text { with the material }\end{array}$ & 88,3 & $\begin{array}{l}\text { Very } \\
\text { Good }\end{array}$ \\
\hline & & $\begin{array}{r}\text { 4. Do you enjoy learning } \\
\text { by using modules this }\end{array}$ & 87,5 & $\begin{array}{l}\text { Very } \\
\text { Good }\end{array}$ \\
\hline & & $\begin{array}{l}\text { 5. Do you understand } \\
\text { more learn by using } \\
\text { modules this }\end{array}$ & 87,5 & $\begin{array}{l}\text { Very } \\
\text { Good }\end{array}$ \\
\hline & & $\begin{array}{l}\text { 6. Is a clue in this } \\
\text { module it's easy to } \\
\text { understand }\end{array}$ & 88,3 & $\begin{array}{l}\text { Very } \\
\text { Good }\end{array}$ \\
\hline & Penyajian & $\begin{array}{l}\text { 1. Does the image in this } \\
\text { module make me } \\
\text { interested in learning }\end{array}$ & 88,3 & $\begin{array}{l}\text { Very } \\
\text { Good }\end{array}$ \\
\hline & & $\begin{array}{l}\text { 2. Is the module cover } \\
\text { good }\end{array}$ & 90,1 & $\begin{array}{l}\text { Very } \\
\text { Good }\end{array}$ \\
\hline & & $\begin{array}{l}\text { 3. Do you like the colors } \\
\text { in the module this }\end{array}$ & 87,5 & $\begin{array}{l}\text { Very } \\
\text { Good }\end{array}$ \\
\hline \multicolumn{3}{|c|}{ Total } & 88,4 & $\begin{array}{l}\text { Very } \\
\text { Good }\end{array}$ \\
\hline
\end{tabular}


4.2 The Effectiveness of PPKn Module on Environmental Love Material by Using the Example Non Example Learning Model

Student learning activities obtained from the observation of student activities. To find out the student activity. The achievements of student activities can be seen in the following table 6 .

Table 6 Student Activity Observation Data

\begin{tabular}{|c|c|c|c|c|c|c|c|c|c|c|c|}
\hline \multirow[t]{3}{*}{ No } & \multirow{3}{*}{$\begin{array}{c}\text { Name of } \\
\text { Responde } \\
\text { nt }\end{array}$} & \multicolumn{10}{|c|}{$\begin{array}{c}\text { Student } \\
\text { activities }\end{array}$} \\
\hline & & \multicolumn{2}{|c|}{ Observe } & \multicolumn{2}{|c|}{ Asking } & \multicolumn{2}{|c|}{ Trying } & \multicolumn{2}{|c|}{ Associate } & \multicolumn{2}{|c|}{$\begin{array}{l}\text { Communic } \\
\text { ating }\end{array}$} \\
\hline & & $\begin{array}{c}\text { Tota } \\
1\end{array}$ & $\begin{array}{c}\text { Percen } \\
\text { tage }\end{array}$ & $\begin{array}{c}\text { Tota } \\
1\end{array}$ & $\begin{array}{l}\text { Perce } \\
\text { ntage }\end{array}$ & $\begin{array}{l}\text { Tot } \\
\text { al }\end{array}$ & $\begin{array}{c}\text { Perc } \\
\text { entag } \\
\mathrm{e}\end{array}$ & $\begin{array}{l}\text { Tot } \\
\text { al }\end{array}$ & $\begin{array}{c}\text { Perc } \\
\text { entag } \\
\text { e }\end{array}$ & $\begin{array}{l}\text { Tot } \\
\text { al }\end{array}$ & $\begin{array}{c}\text { Perc } \\
\text { entag } \\
\mathrm{e}\end{array}$ \\
\hline 1 & Adytia & 51 & 91 & 74 & 84 & 35 & 87,5 & 18 & 90 & 31 & 86,1 \\
\hline 2 & Camelia & 48 & 85,7 & 80 & 90,9 & 33 & 82,5 & 18 & 90 & 30 & 83,3 \\
\hline 3 & Chelsi & 50 & 89,2 & 76 & 86,3 & 37 & 92,5 & 16 & 80 & 32 & 88,8 \\
\hline 4 & Daten & 49 & 87,5 & 74 & 84 & 35 & 87,5 & 17 & 85 & 30 & 83,3 \\
\hline 5 & Elprendy & 47 & 83,9 & 71 & 80,6 & 34 & 85 & 17 & 85 & 27 & 75 \\
\hline 6 & Eros & 49 & 87,5 & 74 & 84 & 36 & 90 & 18 & 90 & 30 & 83,3 \\
\hline 7 & Esterlita & 48 & 85,7 & 72 & 81,8 & 33 & 82,5 & 17 & 85 & 29 & 80,5 \\
\hline 8 & Evan & 50 & 89,2 & 71 & 80,6 & 33 & 82,5 & 15 & 75 & 29 & 80,5 \\
\hline 9 & Fionaclara & 50 & 89,2 & 76 & 86,3 & 36 & 90 & 18 & 90 & 29 & 80,5 \\
\hline 10 & Florencia & 49 & 87,5 & 76 & 86,3 & 35 & 87,5 & 16 & 80 & 31 & 86,1 \\
\hline 11 & Gael & 46 & 82,1 & 73 & 82,9 & 33 & 82,5 & 16 & 80 & 30 & 83,3 \\
\hline 12 & Griselda & 49 & 87,5 & 77 & 87,5 & 34 & 85 & 18 & 90 & 31 & 86,1 \\
\hline 13 & Hanna & 48 & 85,7 & 73 & 82,9 & 34 & 85 & 18 & 90 & 30 & 83,3 \\
\hline 14 & Imoti & 48 & 85,7 & 74 & 84 & 33 & 82,5 & 18 & 90 & 30 & 83,3 \\
\hline 15 & Jea & 43 & 76,7 & 72 & 81,8 & 30 & 75 & 17 & 85 & 27 & 75 \\
\hline 16 & Khairani & 50 & 89,2 & 72 & 81,8 & 34 & 85 & 18 & 90 & 30 & 83,3 \\
\hline 17 & Kevin & 49 & 87,5 & 75 & 85,2 & 34 & 85 & 17 & 85 & 31 & 86,1 \\
\hline 18 & Keyla & 51 & 91 & 75 & 85,2 & 33 & 82,5 & 18 & 90 & 30 & 83,3 \\
\hline 19 & Marelvin & 49 & 87,5 & 75 & 85,2 & 35 & 87,5 & 18 & 90 & 31 & 86,1 \\
\hline 20 & Mhd aqil & 50 & 89,2 & 77 & 87,5 & 35 & 87,5 & 18 & 90 & 31 & 86,1 \\
\hline 21 & Nabila & 48 & 85,7 & 77 & 87,5 & 33 & 82,5 & 17 & 85 & 30 & 83,3 \\
\hline 22 & Nazwa & 50 & 89,2 & 80 & 90,9 & 35 & 87,5 & 18 & 90 & 32 & 88,8 \\
\hline 23 & Owen & 50 & 89,2 & 80 & 90,9 & 36 & 90 & 19 & 95 & 32 & 88,8 \\
\hline 24 & Pieter & 52 & 92,8 & 78 & 88,6 & 34 & 85 & 19 & 95 & 31 & 86,1 \\
\hline 25 & Putra & 44 & 78,5 & 73 & 82,9 & 30 & 75 & 17 & 85 & 27 & 75 \\
\hline 26 & Rangga & 50 & 89,2 & 76 & 86,3 & 34 & 85 & 18 & 90 & 31 & 86,1 \\
\hline 27 & Yamolo'o & 49 & 87,5 & 82 & 93 & 34 & 85 & 19 & 95 & 34 & 94,4 \\
\hline 28 & Zevanya & 50 & 89,2 & 78 & 88,6 & 33 & 82,5 & 18 & 90 & 30 & 83,3 \\
\hline \multicolumn{2}{|c|}{ Average } & 1449 & 92,4 & 2111 & 85,6 & 951 & 84,9 & 501 & 89,4 & 846 & 83,9 \\
\hline
\end{tabular}


Based on the table above, it can be concluded that the prominent student activity, namely the Observing activity with a percentage of $92.4 \%$, then the activity Associating with a percentage of $89.4 \%$, the questioning activity with a percentage of $85.6 \%$, the activity of trying with a percentage of $84.9 \%$ and the activity communicates with a percentage of 83.9

\section{Conclusion}

The process of developing the PPKn module on environmental love using the example non example learning model is carried out in three stages, namely a preliminary study stage, initial product development and product trials. In the preliminary study stage, a needs analysis for teachers and students is conducted. The results of the needs analysis showed that $100 \%$ of teachers needed a companion module in learning PPKn. In the initial product development stage, product design and product validation are carried out to 1 material expert, 1 linguist there is 1 design expert. After the validation process, the product is declared eligible to be tested. In the third stage product trials are carried out in three ways namely individual trials, small group trials and limited field trials. Individual trials get an average percentage of 80.5 with the "Good" category, small group trials get an average percentage of 85.4 with the "Very good" category. Limited field trials received an average percentage of 88.4 in the "Very Good" category. Based on these data, it is obtained a module that is suitable for use by teachers and students in learning.

The level of eligibility is known based on the feasibility assessment of one material expert lecturer, one language expert lecturer and one design expert.

1. Feasibility assessment by material experts obtained an average score of 3.61 and $91.6 \%$ (Very good).

2. Feasibility assessment by linguists obtained an average score of 3.75 and $92.1 \%$ (Very good).

3. Feasibility assessment by design experts obtained an average score of 3.63 and $80 \%$ (Good)

The PPKn module on environmental love material by using the example non example learning model was declared effective to generate student learning activities and outcomes. This is evidenced from the student learning achievement test. At the time of the pretest the average value of students was obtained 69.8 and after using the module (posttest) that is 82.3

Based on the data obtained a significant difference in the increase of $12.5 \%$. which indicates that learning by using the PPKn module on environmental love using the example non example learning model is better than before.

\section{References}

Cogan J. (1999). Developing the Civic Society: The Role of Civic Education (Bandung: CICE Depdiknas. (2003). Kurikulum 2004 Standart Kompetensi. Jakarta: Puskur. Dit. PTKSD

Hamzah, Andi. (2005). Hukum Acara Pidana Indonesia, Jakarta: Sinar Grafika. Ibrahim, M. 2000. Pembelajaran Kooperatif. Surabaya: University sPress.

Joyce, B \& Weil. (2009). Model-model Pengajaran. Edisi 8. Terjemahan A. Fuwaid \& A. Mirza. Yogyakarta: Pustaka Pelajar. 
Komalasari, K., Saripudin, D., \& Masyitoh, I. M. (2014). Living values education model in learning and extracurricular activities to construct the students' character. Journal of Education and Practice, 5(7), 166-174.

Nur, M. dan Wikandari, P.R. (2000). Pengajaran Berpusat kepada Siswa dan Pendekatan Konstruktivistik dalam Pengajaran. Surabaya: Universitas Negeri Surabaya.

Putra, N. (2013). Research \& Development. Jakarta: Raja Grafindo Persada Jakarta. Rochyandi, Yadi. (2004). Model Pembelajaran Kooperatif. Surabaya: Masmedia Buana Pustaka

Rahmanisa, A. (2018). Charactered Education in Learning Indonesian Language in the High School: Case Study in SMAN 1 Surakarta, Indonesia. Budapest International Research and Critics Institute (BIRCI-Journal), P. 29-39.

Rusman. (2011). Model-Model Pembelajaran Mengembangkan Profesionalisme Guru. Jakarta: Rajagrafindo Persada.

Slavin, Robert. (2002). Kooperatif Learning, Jakarta: Rineka Cipta.

Sugiyono. (2010). Metode Penelitian Pendidikan Pendekatan Kuantitatif, kualitatif, dan $R \& D$. Bandung: Alfabeta.

Susanto, A. (2013). Teori Belajar dan Pembelajaran di Sekolah Dasar. Jakarta: Kencana Prenada media Group.

Suprijono, A. (2009). Cooperative Learning, Teori \& Aplikasi PAIKEM. Surabaya: Pustaka Pelajar

Sukardjo. (2008). Kumpulan Materi Evaluasi Pembelajaran. Prodi Teknologi Pembelajaran. PPs. UNY.https://swastyastu.wordpress.com/indikator-dari-aktivitas-belajar 